\title{
Anxiolytic activity of ferulic acid in the light-dark test in zebrafish
}

\author{
Atividade ansiolítica do ácido ferúlico no teste claro-escuro em zebrafish \\ Actividad ansiolítica del ácido ferúlico en la prueba de luz-oscuridad en zebrafish
}

Received: 08/26/2021 | Reviewed: 09/01/2021 | Accept: 09/08/2021 | Published: 09/11/2021

\author{
Susi Mara Soecki Sborgi \\ ORCID: https://orcid.org/0000-0002-0381-366X \\ Universidade Estadual de Ponta Grossa, Brazil \\ E-mail: smsoecki@gmail.com \\ Lillian Caroline Fernandes \\ ORCID: https://orcid.org/0000-0002-7557-5285 \\ State University of Ponta Grossa, Brazil \\ E-mail: lilliancarolfernandes@hotmail.com \\ Anderson Gustavo Santos \\ ORCID: https://orcid.org/0000-0001-7338-2925 \\ Universidade Estadual de Ponta Grossa, Brazil \\ E-mail: ander-gustavo@ @otmail.com \\ Marcelo Machado Ferro \\ ORCID: https://orcid.org/0000-0003-2939-072X \\ Universidade Estadual de Ponta Grossa, Brazil \\ E-mail: mferro@uepg.br \\ Edmar Miyoshi \\ ORCID: https://orcid.org/0000-0001-6159-0532 \\ Universidade Estadual de Ponta Grossa, Brazil \\ E-mail: edmar@uepg.br
}

\begin{abstract}
The anxiety disorders belong to a group of mental disorders in which the patients present excessive fear and worry. Studies with ferulic acid have shown positive results on treating depressive symptoms. As many antidepressive drugs are effective in treating anxiety, the objective of the present study was to evaluate ferulic acid's anxiolytic activity and possible mechanism of action in the light-dark test in zebrafish. To evaluate anxiolytic activity, the light-dark preference test was performed after exposure of the animals to ferulic acid or positive control (clonazepam or fluoxetine). Ferulic acid increased the time spent in the clear compartment at concentrations of $250 \mathrm{and} 500 \mathrm{mg} / \mathrm{L}$, not differing from the groups exposed to clonazepam or fluoxetine. To evaluate the possible mechanism of action, preexposure to flumazenil was carried out, followed by exposure to ferulic acid or positive control, with subsequent testing. Pre-exposure to flumazenil caused a significant reduction in the time spent in the clear compartment of ferulic acid and clonazepam groups but did not alter the effect of exposure to fluoxetine. These results suggest that ferulic acid promotes an anxiolytic effect, possibly through an action at the benzodiazepine binding site at the $\mathrm{GABA}_{\mathrm{A}}$ receptor.
\end{abstract}

Keywords: Zebrafish; Ferulic acid; Anxiety.

\section{Resumo}

Os distúrbios de ansiedade pertencem a um grupo de transtornos mentais onde os pacientes apresentam medo e preocupação excessivos. Estudos com ácido ferúlico têm demonstrado resultados positivos para tratar sintomas depressivos. Como muitas drogas antidepressivas são eficientes no tratamento de ansiedade, o objetivo do presente estudo foi avaliar a atividade ansiolítica e seu possível mecanismo de ação no teste claro/escuro em zebrafish. Para avaliar a atividade ansiolítica, foi realizado o teste de preferência claro-escuro após a exposição dos animais ao ácido ferúlico ou controle positivo (clonazepam ou fluoxetina). O ácido ferúlico aumentou o tempo de permanência no compartimento claro nas concentrações de 250 e $500 \mathrm{mg} / \mathrm{L}$, não diferindo dos grupos expostos ao clonazepam ou fluoxetina. Para avaliar o possível mecanismo de ação, foi realizada a pré-exposição ao flumazenil, seguido da exposição ao ácido ferúlico ou controle positivo, com posterior realização do mesmo teste. O resultado demonstrou que a pré-exposição ao flumazenil promoveu uma redução significativa do tempo de permanência no compartimento claro no grupo exposto com ácido ferúlico e clonazepam, mas não alterou o efeito da exposição a fluoxetina. Estes resultados sugerem que o ácido ferúlico promove um efeito ansiolítico, possivelmente através de uma ação no sitio de ligação benzodiazepínico no receptor $\mathrm{GABA}_{\mathrm{A}}$.

Palavras-chave: Zebrafish; Ácido ferúlico; Ansiedade. 


\section{Resumen}

Los trastornos de ansiedad pertenecen a un grupo de trastornos mentales en los que los pacientes muestran un miedo y una preocupación excesivos. Los estudios con ácido ferúlico mostraron resultados positivos para tratar los síntomas depresivos. Partiendo del hecho de que muchos fármacos antidepresivos son eficaces en el tratamiento de la ansiedad, el objetivo del presente estudio fue evaluar la actividad ansiolítica y su posible mecanismo de acción en la prueba de luz/oscuridad del zebrafish. Para evaluar la actividad ansiolítica, se realizó la prueba de preferencia luz-oscuridad después de exponer a los animales a ácido ferúlico o control positivo (clonazepam o fluoxetina). El ácido ferúlico aumentó el tiempo de permanencia en el compartimento de luz a concentraciones de 250 y $500 \mathrm{mg} / \mathrm{L}$, sin diferenciarse de los grupos expuestos a clonazepam o fluoxetina. Para evaluar el posible mecanismo de acción se realizó una preexposición a flumazenil, seguida de exposición a ácido ferúlico o control positivo, con posterior realización de la misma prueba. El resultado mostró que la preexposición al flumazenil promovió una reducción significativa en el tiempo de permanencia en el compartimento de luz en el grupo expuesto al ácido ferúlico y al clonazepam, pero no cambió el efecto de la exposición a la fluoxetina. Estos resultados sugieren que el ácido ferúlico promueve un efecto ansiolítico, posiblemente a través de una acción en el sitio de unión de las benzodiacepinas en el receptor $\mathrm{GABA}_{\mathrm{A}}$.

Palabras clave: Zebrafish; Ácido ferúlico; Ansiedad.

\section{Introduction}

Over the years, a demographic shift towards the older age that has been happening for generations will reach its peak, and by 2050, 2 billion individuals will be over 60. Common mental disorders, such as anxiety and depression, are known to cause suffering for both patients and their families. Also, with increasing age, they become increasingly deleterious to health and cognition, and even increase mortality in the elderly (Lenze \& Wetherell, 2011).

Anxiety is a normal adaptation mechanism used by humans, smaller rodents and fish to face potential danger. However, in humans, this state of cognitive and behavioral preparation, when exaggerated, impairs the ability to respond appropriately to the environment, generating associated negative economic and social implications (Benneh et al., 2017).

Anxiety disorders are among the most common psychiatric disorders. Patients present significant social and professional disability, poor quality of life, increased risk of suicide and frequent medical services (Ammar, Naja, \& Pelissolo, 2015).

Research of human brain disorders has been using rodent models for a long time, but they present high costs. The zebrafish (Danio rerio) has received attention as a powerful animal model for a wide range of disorders of the human brain. It is a small, inexpensive and genetically treatable aquatic vertebrate species with a high degree of morphological, physiological and genetic homology to humans. It exhibits high fecundity, wide availability of mutant strains, and ability to use cutting-edge in vivo techniques, such as optogenetics. Its genome is completely sequenced and shows orthologs corresponding to more than $80 \%$ of disease-related genes in humans. Although there are substantial differences between brains of zebrafish and humans, the signs that regulate anxiety are similar at the molecular level. All of this reinforces the potential of using these animals to investigate human neuropsychiatric disorders, including genetic or environmental factors that cause anxiety disorders and may contribute to the development of new strategies to prevent or treat them (Khan et al., 2017; Parker, Millington, Combe, \& Brennan, 2012; Richendrfer, Pelkowski, Colwill, \& Creton, 2012).

Although there are a considerable range of drugs to treat anxiety disorders, a substantial number of patients are resistant or suffer their side effects. To increase treatment options, it is necessary to search for new molecules with greater therapeutic efficacy than the existing drugs. In that point of view, compounds obtained from plants represent an excellent source for the discovery of new substances with therapeutic potential (Machado et al., 2015).

Studies suggest that ferulic acid (FA), a phenolic compound present in many staple foods, has antidepressant activity, especially in rodents (Chen, Lin, Zhang, Li, \& Zhang, 2015; Li et al., 2015; Liu et al., 2017; Zeni, Camargo, \& Dalmagro, 2017). As drugs classified as antidepressant are also useful in the treatment of anxiety disorders, the objective of the present study was to evaluate whether FA has anxiolytic activity and if this effect could involve GABA $\mathrm{A}_{\mathrm{A}}$ receptors, using the light-dark 
test in Danio rerio fish.

\section{Methodology}

\section{Animals (animals and housing)}

Adult zebrafish (4 to 6 months, 50-50\% male:female ratio) were kept in tanks (1 fish per liter), filled with chlorinefree water, mechanically and chemically filtered, temperature controlled $\left(26 \pm 2^{\circ} \mathrm{C}\right)$, $\mathrm{pH}$ between 7,0 and 8,0 and light-dark cycle of 14/10 hours (07:00 am - 09:00 pm). The animals were fed with a commercial fish chow (Alcon BASIC®, Alcon, Brazil). All animals used in this study were "naive", healthy and free of signs of disease. They were maintained according to the National Institute of Health Guide for Care and Use of Laboratory Animals (2011). This research was approved by the Ethics Committee on the Use of Animals at the Universidade Estadual de Ponta Grossa on the Process: 029/2017.

\section{Drugs}

Trans-ferulic acid (Pharmanostra, Brazil), clonazepam (Rivotril@ $2.5 \mathrm{mg} / \mathrm{L}$, Roche, Brazil), flumazenil (injectable solution $0.5 \mathrm{mg} / 5 \mathrm{~mL}$, BioChimico, Brazil) and fluoxetine (ViaFarma, Brazil).

\section{Procedures}

To evaluate the anxiolytic activity of FA and the involvement of the GABAergic system in the mechanism of action of FA, we carried out an experimental quantitative research as follows:

\section{Evaluation of anxiolytic activity:}

The fish were divided into the following groups ( $\mathrm{N}=14$ per group): 1) negative control (ethanol solution $5.2 \mathrm{mg} / \mathrm{L}$ ); 2) clonazepam $0.75 \mathrm{mg} / \mathrm{L}$; 3) fluoxetine $10 \mathrm{mg} / \mathrm{L}$; 4) FA $100 \mathrm{mg} / \mathrm{L}$; 5) FA $250 \mathrm{mg} / \mathrm{L}$ and 6) FA $500 \mathrm{mg} / \mathrm{L}$. All drugs were prepared as a $300 \mathrm{ml}$ solution in which the fish remained individually for 10 minutes before being placed in the test tank. The water used for the preparation of the solutions was from the dwelling tank. As FA is photosensitive, the container of the exposure solution was coated with foil. Likewise, the containers with the control solutions were coated so that the stress caused in the animals was similar. Ethanol was used as negative control because it was necessary to prepare FA solutions. FA solutions were prepared by dissolving $0.2 \mathrm{~g}$ in $2900 \mu \mathrm{L}$ absolute ethyl alcohol and concentrations of 100,250 and $500 \mathrm{mg} / \mathrm{L}$ were obtained by dilution in water. The ethanol solution was prepared just before each the test. In a pilot experiment, fish exposed to ethanol has performed equally compared with fish exposed to pure water (data not shown).

\section{Evaluation of the involvement of the GABAergic system in the FA mechanism of action}

The fish were divided into groups ( $\mathrm{N}=14$ per group): 1) negative control (ethanol solution $5.2 \mathrm{mg} / \mathrm{L}$ ); 2) FA 500 $\mathrm{mg} / \mathrm{L}$ and 3) flumazenil $1.25 \mathrm{mg} / \mathrm{L}+\mathrm{FA} 500 \mathrm{mg} / \mathrm{L}$. The animals in group 3 were pre-exposed individually for 20 minutes to flumazenil and then exposed to the $500 \mathrm{mg} / \mathrm{L} \mathrm{FA}$ solution for 10 minutes. The animals of groups 1 and 2 were exposed only to the negative control or the FA. After exposure, the animals were placed in the light-dark test tank.

\section{Light-dark preference test}

This test was performed in a tank $(18 \times 9 \times 7 \mathrm{~cm}$, length $\times$ width $\times$ height $)$ divided into 2 equal parts, one with black background, sides and cover (dark side) and another with white background and sides but without cover, allowing light input (light side). Between these two parts was a black colored slide that could be lifted from the bottom of the aquarium. In the test, the fish were placed in this tank in the clear compartment, filled with dwelling tank water up to a height of $3 \mathrm{~cm}$, without 
drugs, and left for 5 minutes. After this time, the gate was opened leaving a space of $1 \mathrm{~cm}$ in the bottom of the tank, allowing its passage to the dark side. After opening the gate, they were filmed for 5 minutes for analysis of: 1) the latency for the first entrance in the dark compartment; 2) the time spent in the light side; and 3) the number of crosses between the compartments. This protocol was previously described by Gebauer et al. (Gebauer et al., 2011).

\section{Statistical analysis}

The data obtained in the light-dark test were analyzed by the Kruskal-Wallis test and Dunn's multiple comparison post-hoc test, and differences were considered significant if $\mathrm{p} \leq 0.05$. The analysis was performed with GraphPad Prism 6 software. The results were expressed as mean \pm standard deviation.

\section{Results}

\section{Anxiolytic activity}

Zebrafish exposed to FA $100 \mathrm{mg} / \mathrm{L}$ didn't differ from negative control on "time spent in the light side" parameter. However, fish exposed to FA $250 \mathrm{mg} / \mathrm{L}$ ( $\mathrm{p}<0.01$ ), FA $500 \mathrm{mg} / \mathrm{L}$ ( $\mathrm{p}<0.001$ ), clonazepam $0.75 \mathrm{mg} / \mathrm{L}$ (p < 0.001) and fluoxetine $10 \mathrm{mg} / \mathrm{L}(\mathrm{p}<0.001)$ spent more time on the light side compared to control group, as can be seen in Figure 1.

Figure 1 - Time spent in the light side.
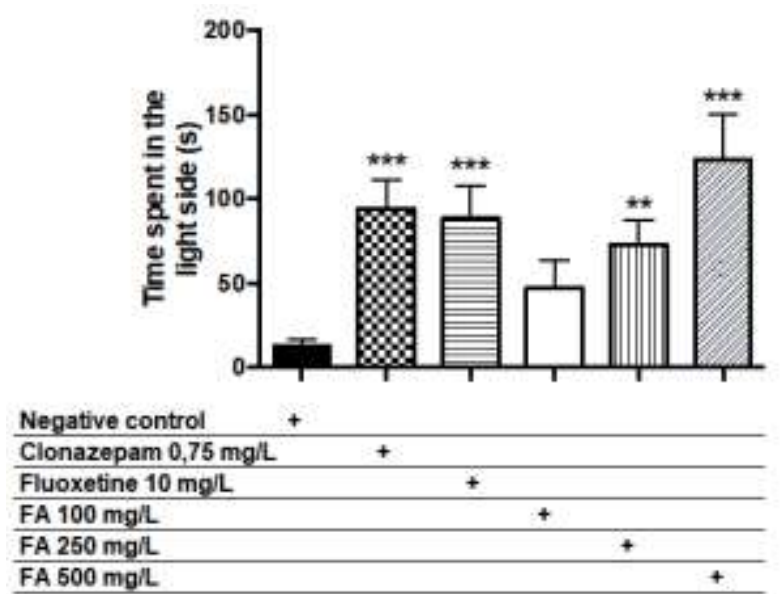

(s): seconds; ** $\mathrm{p} \leq 0.01$, compared to the control group; $* * * \mathrm{p} \leq 0.001$, compared to the control group, Kruskal-Wallis test, followed by Dunn's post-hoc test. Source: Authors.

Consistently, Figure 2 shows that fluoxetine (p < 0.01), FA $250 \mathrm{mg} / \mathrm{L}(\mathrm{p}<0.05)$ and FA $500 \mathrm{mg} / \mathrm{L}(\mathrm{p}<0.05)$ groups presented higher latency for the first entry into the dark compartment, while FA $100 \mathrm{mg} / \mathrm{L}$ clonazepam $0.75 \mathrm{mg} / \mathrm{L}$ groups latencies were similar from control group. 
Figure 2 - Latency for the first entry into the dark compartment.

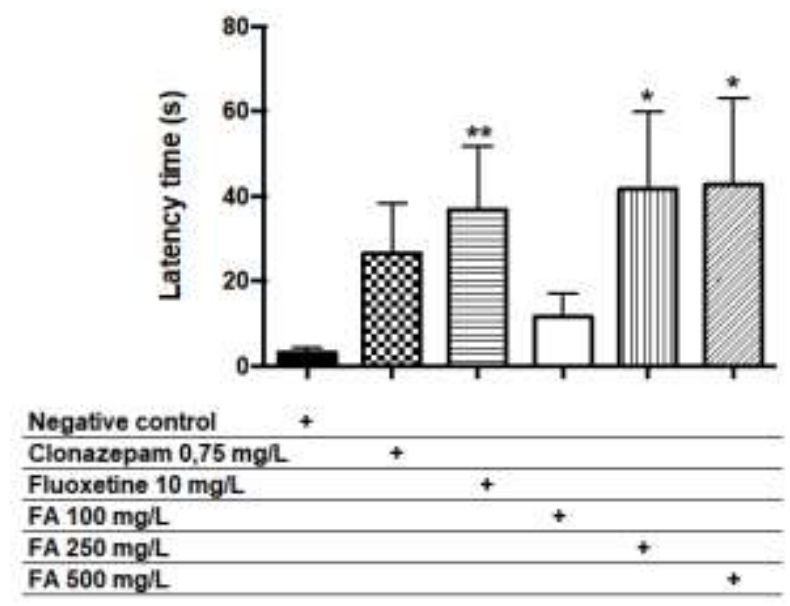

(s): seconds; $* \mathrm{p} \leq 0.05$, compared to the control group; $* * \mathrm{p} \leq 0.01$, compared to the control group compared to the control group, KruskalWallis test, followed by Dunn's post-hoc test. Source: Authors.

There was no difference between the groups on the number of crosses between light and dark compartments (Figure 3).

Figure 3 - Number of crosses between light and dark compartments.

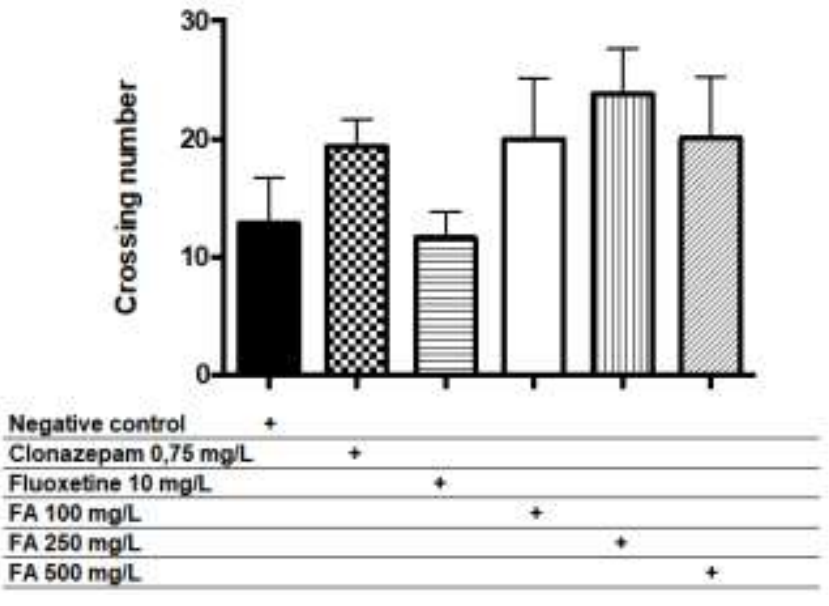

Source: Authors.

\section{Involvement of GABAergic system in the mechanism of action of FA:}

As can be seen on Figure 4, FA $500 \mathrm{mg} / \mathrm{L}$ spent more time in the light side of the tank than the control group (p < 0.001), while flumazenil $1.25 \mathrm{mg} / \mathrm{L}+\mathrm{AF} 500 \mathrm{mg} / \mathrm{L}$ treated fish spent less time on the light side compared to FA 500 mg/L (p $<0.01$ ) but didn't behave differently from control group.

Considering the latency for first entry into the dark compartment, FA $500 \mathrm{mg} / \mathrm{L}$ exposed fish took longer to enter the dark side than control ( $<$ 0.001) and flumazenil $1.25 \mathrm{mg} / \mathrm{L}+$ FA $500 \mathrm{mg} / \mathrm{L}$ groups $(\mathrm{p}<0.01)$ (Figure 5). Also, there were no differences between control and flumazenil $1.25 \mathrm{mg} / \mathrm{L}+$ FA $500 \mathrm{mg} / \mathrm{L}$ groups.

Furthermore, Figure 6 shows that the association of flumazenil $1.25 \mathrm{mg} / \mathrm{L}$ with FA $500 \mathrm{mg} / \mathrm{L}$ provoked fewer crosses between light and dark compartments than both control (p < 0.01) and FA $500 \mathrm{mg} / \mathrm{L}(\mathrm{p}<0.05)$ groups, while FA 500 mg/L number of crosses was no different from control. 
Figure 4 - Time spent in light side.

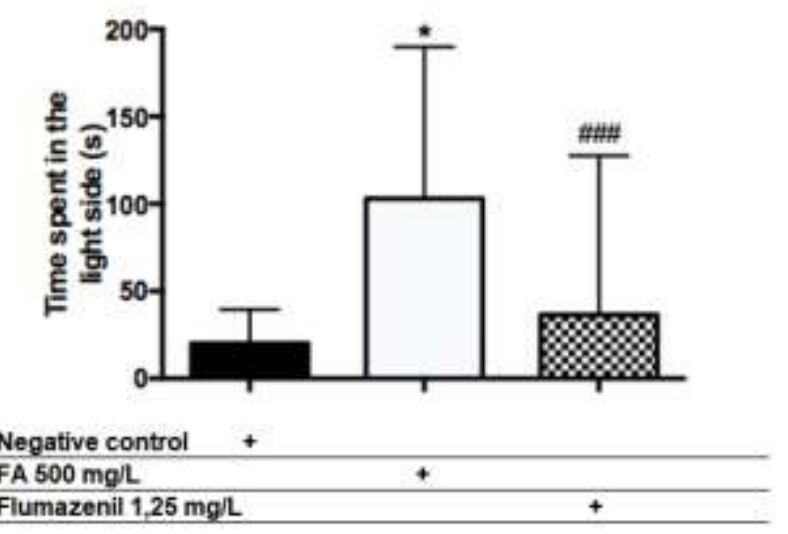

(s): seconds; * $\mathrm{p} \leq 0.05$, compared to the control group; \#\# $\mathrm{p} \leq 0.001$, compared to the AF $500 \mathrm{mg} / \mathrm{L}$ group, Kruskal-Wallis test, followed by Dunn's post-hoc test. Source: Authors.

Figure 5 - Latency for first entry into the dark compartment.

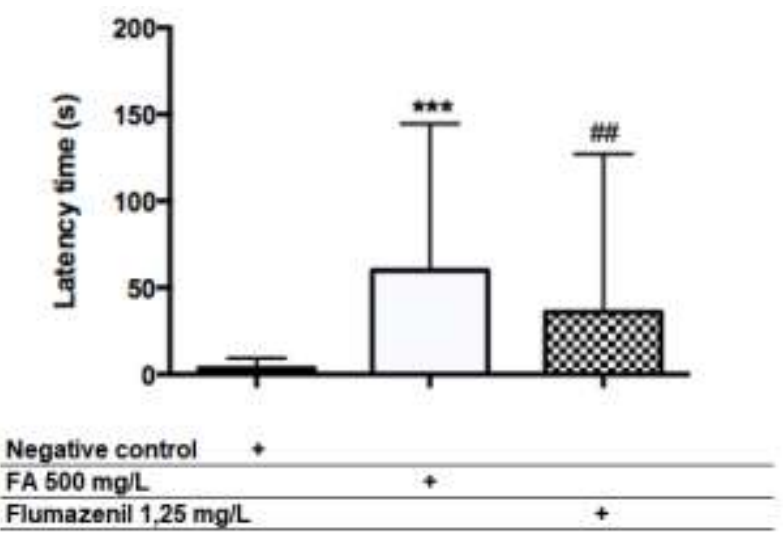

(s): seconds; *** $\mathrm{p} \leq 0.001$, compared to the control group; \# $\mathrm{p} \leq 0.05$, compared to the AF $500 \mathrm{mg} / \mathrm{L}$ group; \#\# $\mathrm{p} \leq 0.01$, compared to the AF $500 \mathrm{mg} / \mathrm{L}$ group, Kruskal-Wallis test, followed by Dunn's post-hoc test. Source: Authors

Figure 6 - Number of crosses between light and dark compartments.

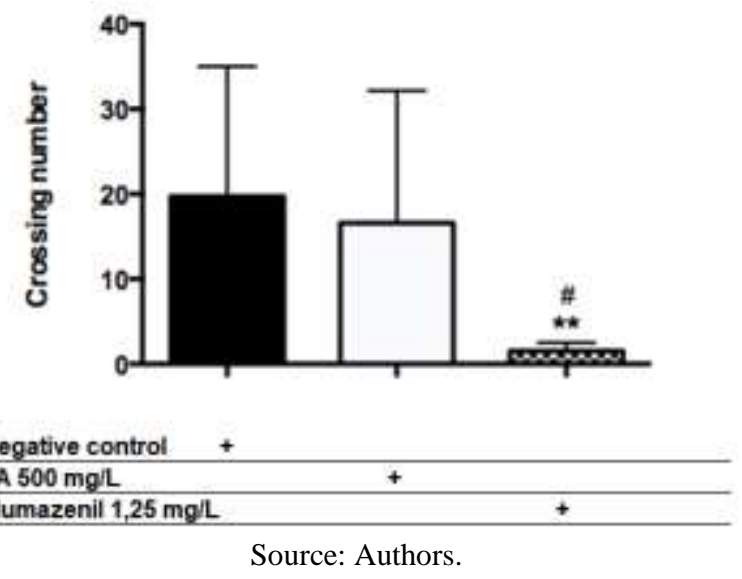

\section{Discussion}

Taken together, the results of the first test (figures 1,2 and 3) indicate that FA had an anxiolytic activity on zebrafish in a concentration-dependent manner on the light-dark paradigm. Although animals exposed to $100 \mathrm{mg} / \mathrm{L}$ did not differ from control group, both higher concentrations caused fish to stay longer in the light side of the tank and increased their latency to enter the dark side. FA at both 250 and $500 \mathrm{mg} / \mathrm{L}$ caused the same alteration on time spent on the light side as both clonazepam 
and fluoxetine-exposed fish, which served as positive control groups. Also, the increment on latency to enter the dark side caused by FA, also an anxiolytic effect, was as high as the provoked by fluoxetine. The fact that the number of crossings between light and dark sides didn't significantly differ among groups means that none of the drugs caused motor alterations during the tests. A motor alteration could influence on the interpretation of the other two behavioral parameters.

As expected, animals exposed to clonazepam and fluoxetine, which are drugs consolidated in the treatment of anxiety disorders, had a significantly longer dwelling time in the clear compartment than those that were not exposed. Hacke, Miyoshi, Marques, \& Pereira (2020) also used clonazepam as a positive control in her study at the same concentration of $(0.75 \mathrm{mg} / \mathrm{L})$ and similarly observed an increase in time spent on the light side of the tank compared to the untreated group. Magno, Fontes, Gonçalves, \& Gouveia (2015) obtained a similar result when exposed zebrafish to clonazepam $0.006 \mathrm{mg} / \mathrm{L}$ for 600 seconds, reporting that exposure decreased the time in the dark, but acute exposure with fluoxetine at concentrations of 2,4 and $6 \mathrm{mg} / \mathrm{L}$ did not decrease this parameter. Likewise, Maximino, da Silva, Gouveia, e Herculano, (2011) observed anxiolytic effect of clonazepam at a dose of $0.05 \mathrm{mg} / \mathrm{kg}$ in the modified light / dark test but only observed this effect for fluoxetine when exposure was chronic; acute exposure at a dose of $10 \mathrm{mg} / \mathrm{kg}$ did not increase the time spent in the clear compartment. In the study by Abreu, Giacomini, Koakoski, Piato, e Barcellos (2017), there was a decrease in the anxiogenic effect in the same species after acute exposure with fluoxetine (50 $\mu \mathrm{g} / \mathrm{L}$, immersion for 15 minutes) in spatial restriction and persecution tests. Another similar result was reported by Maximino, C., Lima, M. G., Costa, C. C., Guedes, I. M. L., \& Herculano, A. M. (2014) at the dose of $2.5 \mathrm{mg} / \mathrm{kg}$ in the new tank test, being in agreement with the results found in our experiment.

Clonazepam is a fast-acting BZD and although this class of drugs is known to have a greater risk of causing memory impairment, addiction and withdrawal symptoms, they remain an important option for patients with high levels of anxiety. Clonazepam is one of the most clinically used drugs of this class, probably because it presents a lower incidence of adverse events due to its low lipid solubility and slower plasmatic half-life. Besides, it also lacks drug interactions with antidepressants, hence the common association of these two classes (Wang et al., 2016). Fluoxetine (SSRI) is widely used for the treatment of anxiety and depression disorders. This drug promotes the inhibition of serotonin reuptake in the presynaptic cell, increasing its extracellular level. Serotonin is a neurotransmitter involved in the regulation of mood, appetite, sleep, memory and learning and is associated with depressive and anxiety conditions. Acute treatment with fluoxetine is also used as a neuropharmacological tool for the study of the serotonergic roll on stress and aggressive behavior of adult zebrafish, as shown by Theodoridi, Tsalafouta, e Pavlidis, (2017).

The light-dark test has been used as a rodent anxiety test for a long time. Animals exposed to anxiolytic drugs have been found to increase the time spent in the clear area, while anxiogenic drugs decrease it. Likewise, zebrafish also shows preference for dark environments, making this parameter potentially useful for assessing the effects of anxiolytics (Gebauer et al., 2011). This work results confirmed the preference for the dark side and the effectiveness of FA at 250 and $500 \mathrm{mg} / \mathrm{L}$; BZD and fluoxetine in increasing the time spent in the clear zone. The assertion by Bourin and Hascoët, that the increased time spent in the light compartment after treatment with a drug is suggested as an index of its anxiolytic activity, corroborates with this work suggestion of a anxiolytic effect of FA on zebrafish, likewise fluoxetine and clonazepam (Bourin \& Hascoët, 2003).

Giacomini et al., (2016) evaluated the effects of acute stress on behavioral parameters in zebrafish exposed to fluoxetine and diazepam using other tests than the light-dark test. In a locomotor evaluation test, they reported that stress increases locomotor activity and that fluoxetine and diazepam do not affect it by themselves, but revert the behavioral changes induced by the acute stress protocol, suggesting that the effects of these drugs may be by blockage of cortisol responses under acute stress. These two drugs did not cause sedation or relevant side effects in this study, as well as in the present study, in which we used the same SSRIs but clonazepam instead of diazepam. If the drugs had caused sedation, the number of crosses would be smaller compared to the control group. 
$\mathrm{Xu}$ et al., (2013) investigated the effect of FA on reserpine-induced pain and depression-like behaviors in mice. In this study, they applied a specific test to evaluate locomotor activity, an ambulometer, with 5 activity chambers. No dose of FA ( 5 to $80 \mathrm{mg} / \mathrm{kg}$ ) affected locomotor activity, although they had significantly influenced the immobility response in tail suspension and forced swimming tests. Likewise, in the tests we performed, there was no difference in the number of crosses between the sides of the tank in the animals exposed to the FA and those not exposed, except for this last test in the group that received pre-exposure to flumazenil followed by exposure to FA $500 \mathrm{mg} / \mathrm{L}$. Thus, we agree with this study that asserted that FA does not affect locomotor activity.

With the objective of help clarifying FA mechanism of action, antagonism of the benzodiazepine (BZD) binding site on $\mathrm{GABA}_{\mathrm{A}}$ receptor was performed previously to zebrafish exposure to the highest FA concentration $(500 \mathrm{mg} / \mathrm{L})$. Results presented on figures (4, 5 and 6) indicate that the FA anxiolytic activity was blocked by flumazenil pre-exposure, as it significantly prevented both the increasing in time spent on the light area and the latency to enter the dark side caused by FA alone. This result suggests action on the FA on the BZD binding site, which could increase $\mathrm{GABA}_{\mathrm{A}}$-induced inhibition of neuron firing, as well as clonazepam (Celik, Deniz, Uzbay, Palaoğlu, \& Ayhan, 1999).

As noted in figure 6, both FA and flumazenil had no effect on locomotor activity. However, the number of crosses between sides was significantly lower in the fish that were exposed to these two associated drugs. Thus, we suggest that this decrease was not due to locomotor effect, but to block the anxiolytic effect of FA.

Celik, Deniz, Uzbay, Palaoğlu, e Ayhan, (1999) carried out a study in which the effects of flumazenil (5, 10 and 20 $\mathrm{mg} / \mathrm{kg}$ administered intraperitoneally) on locomotor activity in rats were analyzed. They concluded that flumazenil has no effect on locomotor activity but that it can reverse locomotor depression caused by the administration of diazepam.

According to the results found in this work, Machado et al. (2015) reported that isopentyl ferulate, a FA ester, also acted on BZD binding site on $\mathrm{GABA}_{\mathrm{A}}$ receptors by reversing its anticonvulsive effect with flumazenil.

\section{Conclusion}

Considering the presented results, it can be asserted that ferulic acid presents anxiolytic activity on zebrafish on the light-dark paradigm and its action apparently occurs through interaction with the GABA receptor. Further electrophysiological studies using the patch-clamp technique can prove the action of ferulic acid on the $\mathrm{GABA}_{\mathrm{A}}$ receptor.

\section{References}

Abreu, M. S., Giacomini, A. C. V. V., Koakoski, G., Piato, A. L. S., \& Barcellos, L. J. G. (2017). Divergent effect of fluoxetine on the response to physical or chemical stressors in zebrafish. PeerJ, 5, e3330. https://doi.org/10.7717/peerj.3330

Ammar, G., Naja, W. J., \& Pelissolo, A. (2015). Troubles anxieux résistants : revue des stratégies de traitements médicamenteux. L’Encéphale, 41(3), 260265. https://doi.org/10.1016/j.encep.2013.11.002

Benneh, C. K., Biney, R. P., Mante, P. K., Tandoh, A., Adongo, D. W., \& Woode, E. (2017). Maerua angolensis stem bark extract reverses anxiety and related behaviours in zebra fi sh - Involvement of GABAergic and 5-HT systems. Journal of Ethnopharmacology, 207, 129-145. https://doi.org/10.1016/j.jep.2017.06.012

Bourin, M., \& Hascoët, M. (2003). The mouse light-dark box test. European Journal of Pharmacology, 463(1-3), 55-65. https://doi.org/10.1007/978-160761-303-9-11

Celik, T., Deniz, G., Uzbay, I. T., Palaoğlu, O., \& Ayhan, I. H. (1999). The effects of flumazenil on two way active avoidance and locomotor activity in diazepam-treated rats. European Neuropsychopharmacology: The Journal of the European College of Neuropsychopharmacology, 9(1-2), 45-50. https://doi.org/10.1016/S0924-977X(97)00101-6

Chen, J., Lin, D., Zhang, C., Li, G., \& Zhang, N. (2015). Antidepressant-like effects of ferulic acid: involvement of serotonergic and norepinergic systems. Metab Brain Dis, (30), 129-136. https://doi.org/10.1007/s11011-014-9635-z

Gebauer, D. L., Pagnussat, N., Piato, A. L., Schaefer, I. C., Bonan, C. D., \& Lara, D. R. (2011). Effects of anxiolytics in zebrafish: similarities and differences between benzodiazepines, buspirone and ethanol. Pharmacology, Biochemistry, and Behavior, 99(3), 480-486. https://doi.org/10.1016/j.pbb.2011.04.021 
Giacomini, A. C. V. V, Abreu, M. S., Giacomini, L. V., Siebel, A. M., Zimerman, F. F., Rambo, C. L., \& Barcellos, L. J. G. (2016). Fluoxetine and diazepam acutely modulate stress induced-behavior. Behavioural Brain Research, 296, 301-310. https://doi.org/10.1016/j.bbr.2015.09.027

Hacke, A. C. M., Miyoshi, E., Marques, J. A., \& Pereira, R. P. (2020). Anxiolytic properties of Cymbopogon citratus (DC.) stapf extract, essential oil and its constituents in zebrafish (Danio rerio). Journal of Ethnopharmacology, 260(January). https://doi.org/10.1016/j.jep.2020.113036

Khan, K. M., Collier, A. D., Meshalkina, D. A., Kysil, E. V, Khatsko, S. L., Kolesnikova, T., \& Echevarria, D. J. (2017). Zebrafish models in neuropsychopharmacology and CNS drug discovery. British Journal of Pharmacology, 174, 1925-1944. https://doi.org/10.1111/bph.13754

Lenze, E. J., \& Wetherell, J. L. (2011). A Lifespan view of anxiety disorders. Dialogues in Clinical Neuroscience, 13(4), 381-399. https://doi.org/10.1097/BOR.0b013e32834b5457

Li, G., Ruan, L., Chen, R., Wang, R., Xie, X., Zhang, M., \& Pan, J. (2015). Synergistic antidepressant-like effect of ferulic acid in combination with piperine: involvement of monoaminergic system. Metab Brain Dis., 30(6), 1505-1514. https://doi.org/10.1007/s11011-015-9704-y.Synergistic

Liu, Y. M., Hu, C. Y., Shen, J. D., Wu, S. H., Li, Y. C., \& Yi, L. T. (2017). Elevation of synaptic protein is associated with the antidepressant-like effects of ferulic acid in a chronic model of depression. Physiology and Behavior, 169, 184-188. https://doi.org/10.1016/j.physbeh.2016.12.003

Machado, K. C., Oliveira, G. L. S., Machado, K. C., Islam, M. T., Junior, A. L. G., De Sousa, D. P., \& Freitas, R. M. (2015). Anticonvulsant and behavioral effects observed in mice following treatment with an ester derivative of ferulic acid: Isopentyl ferulate. Chemico-Biological Interactions, 242, 273-279. https://doi.org/10.1016/j.cbi.2015.10.003

Magno, L. D. P., Fontes, A., Gonçalves, B. M. N., \& Gouveia, A. (2015). Pharmacological study of the light-dark preference test in zebrafish (Danio rerio): Waterborne administration. Pharmacology Biochemistry and Behavior, 135, 169-176. https://doi.org/10.1016/j.pbb.2015.05.014

Maximino, C., da Silva, A. W. B., Gouveia, A., \& Herculano, A. M. (2011). Pharmacological analysis of zebrafish (Danio rerio) scototaxis. Progress in Neuro-Psychopharmacology and Biological Psychiatry, 35(2), 624-631. https://doi.org/10.1016/j.pnpbp.2011.01.006

Parker, M. O., Millington, M. E., Combe, F. J., \& Brennan, C. H. (2012). Development and implementation of a three-choice serial reaction time task for zebrafish ( Danio rerio ). Behav Brain Res, 227(1), 73-80. https://doi.org/10.1016/j.bbr.2011.10.037.Development

Richendrfer, H., Pelkowski, S. D., Colwill, R. M., \& Creton, R. (2012). On the edge: pharmacological evidence for anxiety-related behavior in zebrafish larvae. Behav Brain Res, 228(1), 99-106. https://doi.org/10.1111/j.1743-6109.2008.01122.x.Endothelial

Theodoridi, A., Tsalafouta, A., \& Pavlidis, M. (2017). Acute exposure to fluoxetine alters aggressive behavior of zebrafish and expression of genes involved in serotonergic system regulation. Frontiers in Neuroscience, 11, 1-9. https://doi.org/10.3389/fnins.2017.00223

Wang, S. M., Kim, J. B., Sakong, J. K., Suh, H. S., Oh, K. S., Woo, J. M., \& Lee, K. U. (2016). The efficacy and safety of clonazepam in patients with anxiety disorder taking newer antidepressants: A multicenter naturalistic study. Clinical Psychopharmacology and Neuroscience, 14(2), 177-183. https://doi.org/10.9758/cpn.2016.14.2.177

Xu, Y., Zhang, L., Shao, T., Ruan, L., Wang, L., Sun, J., \& Pan, J. (2013). Ferulic acid increases pain threshold and ameliorates depression-like behaviors in reserpine-treated mice: Behavioral and neurobiological analyses. Metabolic Brain Disease, 28(4), 571-583. https://doi.org/10.1007/s11011-013-9404-4

Zeni, A. L. B., Camargo, A., \& Dalmagro, A. P. (2017). Ferulic acid reverses depression-like behavior and oxidative stress induced by chronic corticosterone treatment in mice. Steroids, 125, 131-136. https://doi.org/10.1016/j.steroids.2017.07.006 